The BDJ News section accepts items that include general news, latest research and diary events that interest our readers. Press releases or articles may be edited, and should include a colour photograph if possible. Please direct your correspondence to the News Editor, Arveen Bajaj at the BDJ, 64 Wimpole Street WIG 8YS or by email to bdj@bda.org

\section{New President}

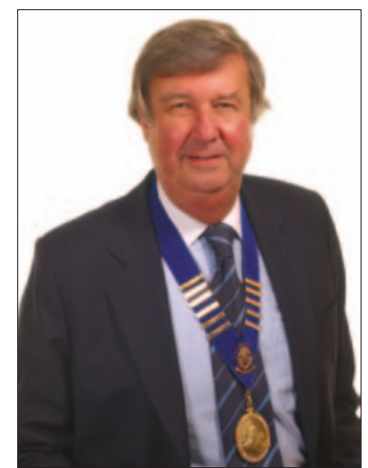

Dr Allan R Thom has been elected President of the British Orthodontic Society. Dr Thom is a Consultant Orthodontist/Honorary Senior Lecturer at Guy's, King's and St. Thomas' Dental Institute and also Consultant Orthodontist at Queen Victoria Hospital in East Grinstead.

He was formally treasurer of the Society and Chairman of the International Committee. His Presidential year will coincide with the World Orthodontic Conference to be held in Paris September 2005.

The British Orthodontic Society was formed in 1994 with the unification of all UK orthodontic associations and societies. Dr Thom is the eleventh President.

\section{Dentist wins national award}

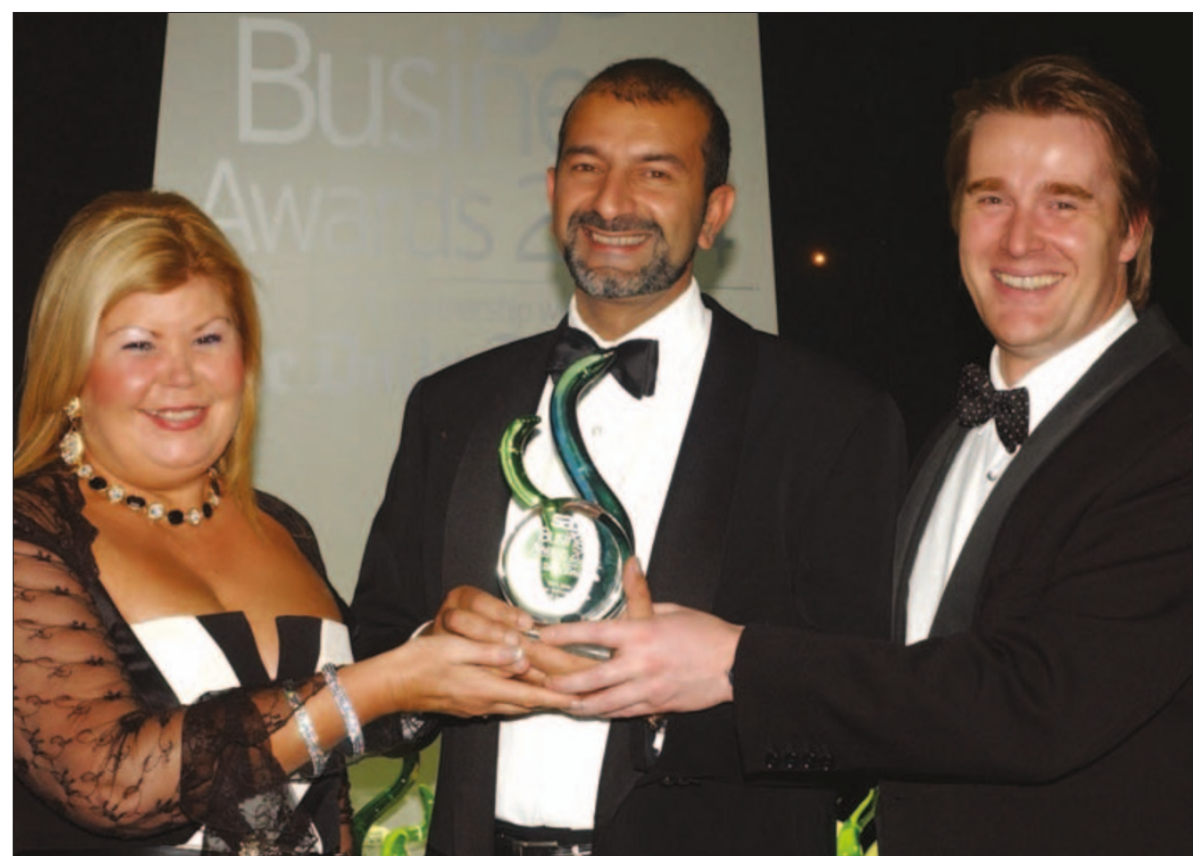

Barbican Dental Care (BDC) owned by Neil Sikka, has become the first dental practice to win the Best New Customer Service Initiative Category at The Sage/Telegraph Business Awards 2004. The practice has previously won local business awards and was delighted to win its first national award. Judges were looking for those businesses who did most not only to look after existing customers but also to attract new ones. BDC has four practices looking after the teeth of busy workers in The City of London and

Canary Wharf and sees around 160 patients a day. Pictured left to right: Catherine Venus, Neil Sikka and Mark Hughes.

\section{Gold medalist}

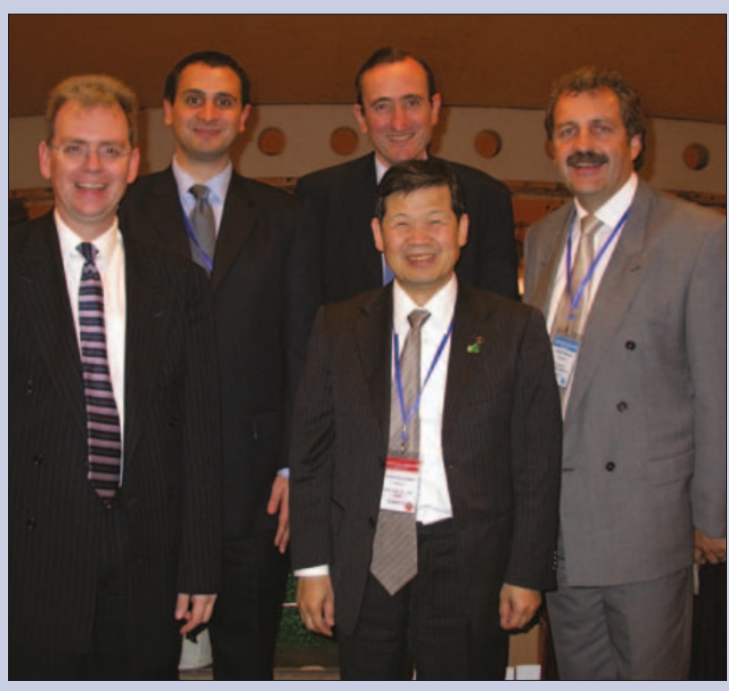

\section{Paediatric dentistry}

A new outreach teaching programme for undergraduate dental students from Bristol Dental School commenced recently at the newly refurbished Charlotte Keele Health Centre in Bristol. The new facility will be able to accept three students at a time who will be supported by qualified nurses while treating children. This new initiative is the first for the school and will be piloted during its first year.

The school also recently celebrated the achievements of one of its graduates Alison Chapman, a SHO in CDH, who won the British Society of Paediatric Dentistry Research poster prize for her presentation 'An oral health education programme based on the National Curriculum'. 


\section{DIARY}

January 2005

OSAP 4th Annual Intermediate-Level Infection Control and Occupational Safety and Health Course

Date: 24-27.01.04

Venue: Hyatt Regency Atlanta, Georgia Tel: 800-298-OSAP (6727)

www.osap.org.

International Dental Foundation 54th International Alpine Dental Conference Date: 29.01.05-05.02.05

Venue: Hotel Annapurna, Courcheval 1850, France

Contact: Robert Wallace

Tel: +44 (0) 2072350788

Fax: +44 (0) 2072350767

Email: idf@idfdentalconference.com www.idfdentalconference.com

\section{March 2005}

83rd General Session \& Exhibition of the IADR, 34th Annual Meeting of the AADR, 29th Annual Meeting of the CADR

Date: 9-12.03.05

Venue: Baltimore Convention Centre www.dentalresearch.org

\section{April 2005}

Academy of Laser Dentistry Source 2005: Lasers in Dentistry

Date: 6-9.04.05

Venue: New Orleans Marriott Hotel, New Orleans, Louisiana, USA

Tel: 1-877-527-3776

Email: memberservices@

laserdentistry.org

www.source2005.org

\section{New dental labs at King's}

King's College London opened new laboratories earlier this month, following a $£ 3.7$ million refurbishment programme aimed at bringing all laboratory-based dental research at King's under one roof.

Professor Paul Sharpe, the head of the new Henry Wellcome Laboratories for Craniofacial Development on floor 27, said that the refurbishment had provided them with dedicated facilities for different types of microscopy. The research teams headed by Professor David Beighton and Dr Gordon Proctor, who were previously housed at Denmark Hill, are the main beneficiaries of the new facilities on floor 17. The new laboratories were opened by Dr Sohaila Rastan, Director of Science Funding at the Wellcome Trust, and Sir Tim Chessells, Chairman of Guy's and St Thomas' Charitable Foundation. Together, these organisations financed the new facilities.

A state-of-the-art mass spectrometer will allow researchers to identify bacterial proteins that are important in tooth decay, with the ultimate aim of developing new therapies. The new equipment has also inspired dental researcher Dr Karen Homer to launch collaborations with other King's College departments, to identify proteins that play a major role in leukaemia and diabetes.

In addition, the refurbishment has provided space for two new specialist research microscopes. A laser-dissection microscope will enable researchers to cut out individual cells from developing teeth for analysis.

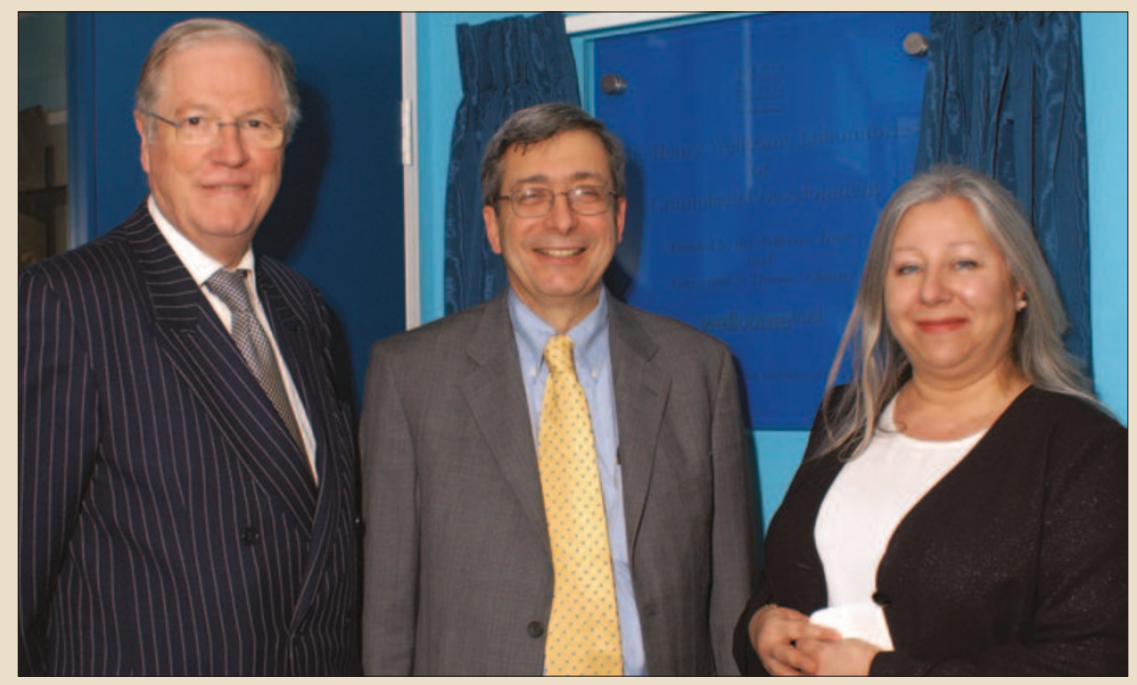

Above from left to right, Sir Tim Chessells, Chairman of the Guy's and St Thomas' Charitable Foundation, Professor Rick Trainor, Principal of King's College London and Dr Sohaila Rastan, Director of Science Funding, The Wellcome Trust. 


\section{RAF dentist wins award}

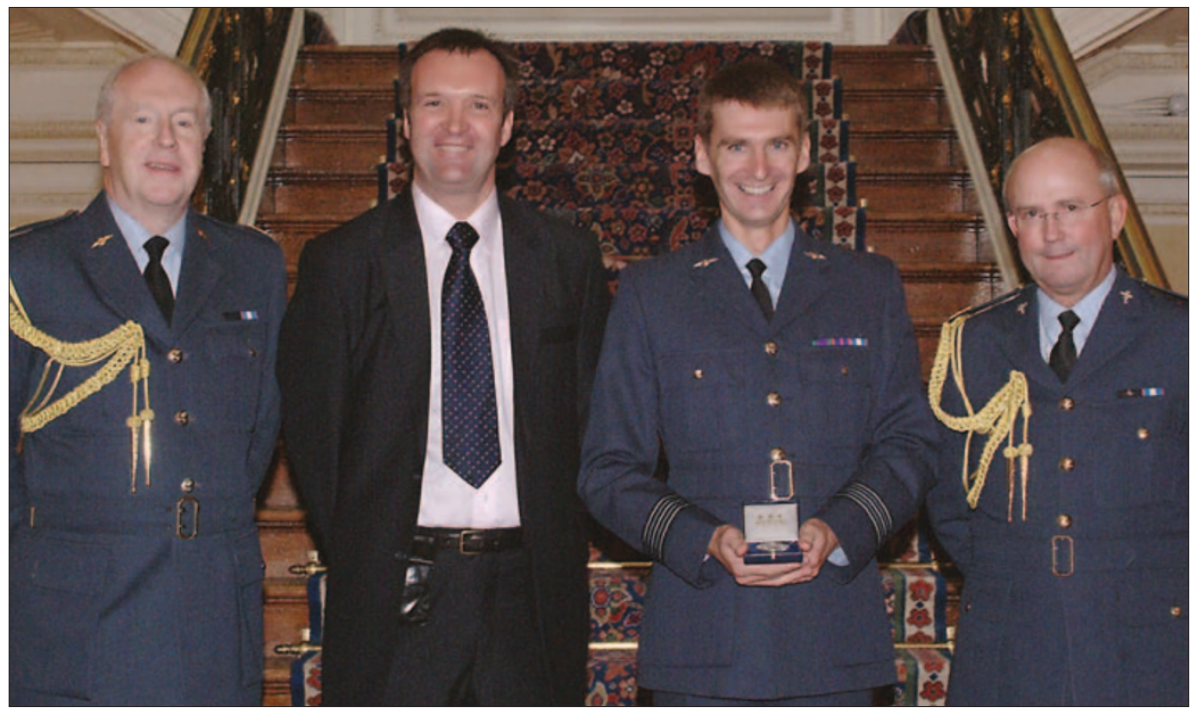

Wing Commander Mark Richardson, based at RAF Kinloss, was recently awarded The Lean Memorial Award for outstanding contribution to the practice of dentistry in the Royal Air Force. The Lean Memorial Award was established by the RAF Dental Branch to commemorate the life and work of Air Vice Marshall D A R Lean who died whilst serving as Director of the Royal Air Force Dental Services in 1982. It was presented by Professor Bill Saunders, Dean of the Dental School, University of Dundee at Halton House Officers' Mess recently. From left to right, Air Commodore John Reid, Director RAF Dental Branch, Professor Bill Saunders, Dean of the Dental School, University of Dundee, winner Wing Commander Mark Richardson and Air ViceMarshal Simon Dougherty, Director General Medical Services (RAF).

\section{liP successes}

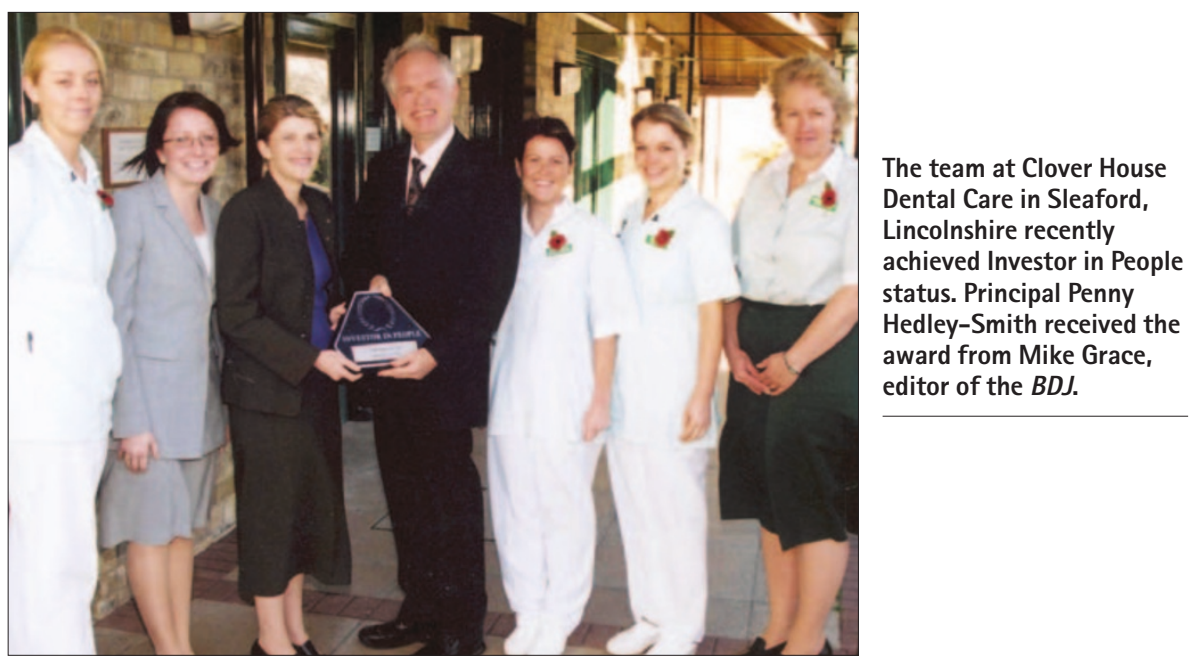

Staff at Mumbles Road Dental Practice in

Mumbles, Swansea have been recognised as an Investor in People. They were presented with the award by leader of the Welsh Conservative Party Nick Bourne on behalf of Education and Learning for Wales.

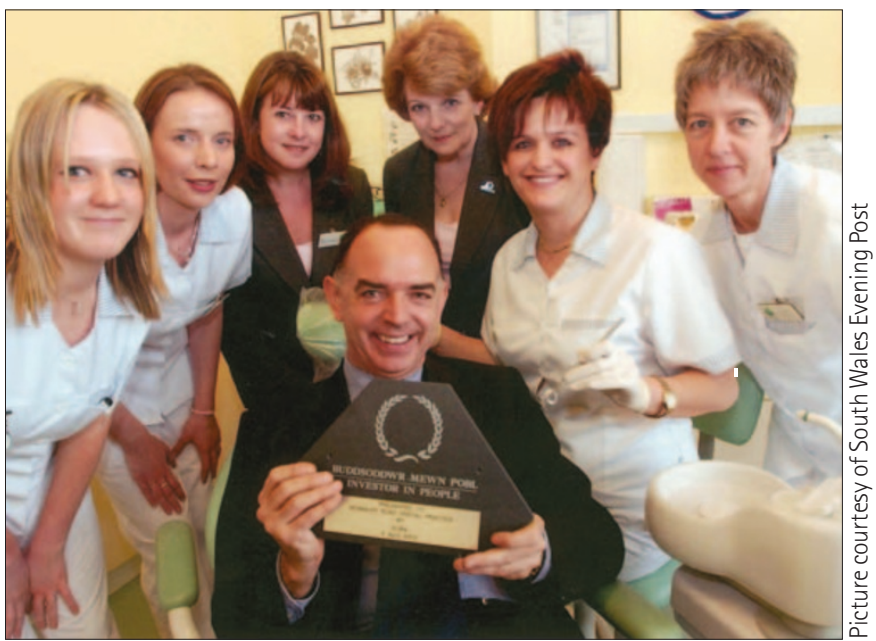

